○酒井國男，须沃八千代，三好敏之，松永亨，内藤售，中村臂二（阪大）

$$
\text { Iはじめに }
$$

現在でも感音性難㯖の治療は困難であり，その成果も突発性難㯖を除くとごく僅かであ る為、難聴者により良い禣㯖器を処方することが必要となつてくる。語音聴力検查は禣 聴器の適用を决めるのに重要であり，補㯖器処方の研究も多々報告されているが，そ北ら には㭪聴器の機能に関するものが多い。現在まで，雑音負倚による語音聴力検查は内外で 報告士水，正常耳，伝音性難㯖耳，感音 性難聴耳においても梌討を加之ら北々き た。同心㯖力像を示す難㯖でも。難㯖の 性算かよで難聴者の知能などによっても 補䏇器の適用は変つてくると考之られる 。今回，我々は实生活により密接したと 考えら水る人の話声を競合音として負荷 した語音明瞭度検查を考之，正常人おお

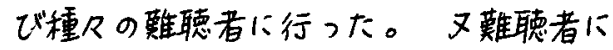
は禣聴器も使用して。その効果について 検討した。

\title{
II 検查方法
}

1) 検查対象対象の正常人40 名は純音㯖力検查およで67ABりストに よる語音明瞭度㛟查に異常のないもので ある。

2）検查語音表 ては，表1に示す如く 主語と述語のそろった わかり也すく、叉やさ しい单語を使った文章 を考之，200文章で1 表として4つの語音表 を作裴した。競合音と しては全く别の内容の 長文朗読を使用した。 録音には，まず基萍音 として $1 \mathrm{kHz}$ の純音 を一定レベルで録音し た後に語音の強さがミ

検查用語音とし

表 1 明瞭度検查用語音表 No I
/. 赤い大が牛と泣いた
2. 青い大゙が馬と笑った
3.男の人が茶色い馬をふんだ
タ.女の人が青い馬に秉った
5、青い車がキりンをはねた
6、赤いキリンが車をふんだ
7. 白い猫が蛙を押之た
8. 青い蛙が魚を食べた
17. 赤いロバが男とぶつかった
18. 青いラクダが男と走った
19.大きな自転事が自動車をは收た
20. 小さな骙行機が電車をは极た

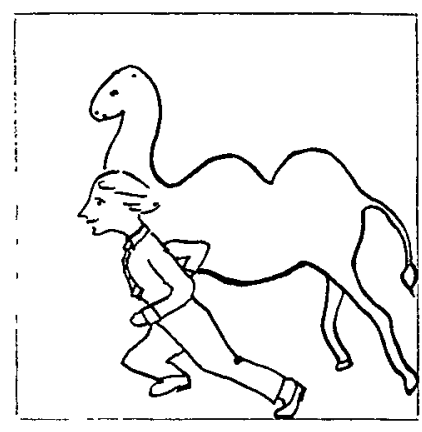

No1 18 9正解

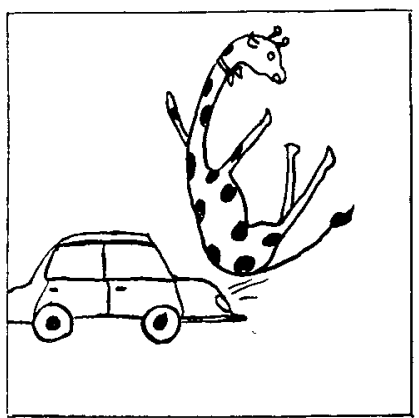

No150正解 
の純音のレベルにほぼ一致するようにテープに録音した。検查音，競合音とも同じ男性す 声を用いた。レベルを一定にしに検查音，競合音のて種の音を一本のステレオテープに録 音した。被検者の応答は文章ジとに、四1に示可㥞尔絵8枚の中から検查音の文章の意味 と一致する絵を一枚展ばせた。

3）検查方法検查は阪大耳萛科防音空で行い検查装是としてSony TC-126

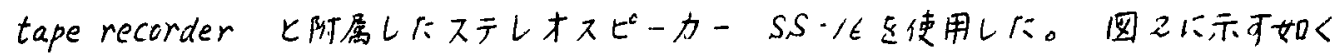
、被検者をステレオスピーカ一の前方およそ1 mの所に坐ら世に。検查に先立つて、リオ

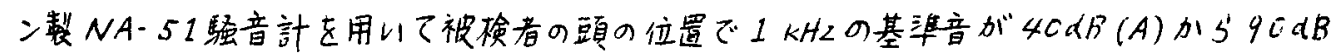
(A) の間で/ $O d B$ 間隔に变化で、るように增幅器のダイヤルを調蓈した。検查音は6C およで70 d B ( A ) に固定して 競合音は検查音/競合音の比（ $S / N$ 比とする）がー20

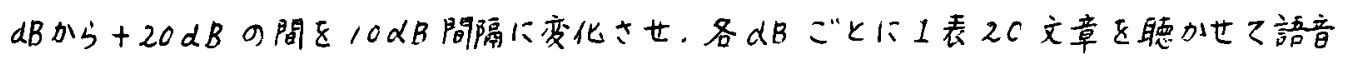
明瞭度を測定した。

\section{II 検查成績}

第人語音表を使用した時の正常人 20名9成䌙を図3に示した。 検查音 $60 d B$ における語音明瞭度で ある。横軸には，検查音/競合音の 比を記した。検香音60dB の時は， $S / N$ 比が-20dB で $35 \%,-10$ $A B$ で $84 \%, O_{d B}$ で $98 \%$, + $10 \mathrm{~dB}$ で $100 \%$ の語音明膫度平均值 を得下。検查音がクCdBでは，S/N 比が-2C $\alpha B$ で $35 \%,-10 \alpha B て ゙ 90$ $\%, O d B て ゙ 99 \%,+10 d B Z 71 C C$ 图 2 検查装置 $\%$ \%゙すた。検查音/競合音の比 が○よBで丙群ともほぼ/ 瞭度を得た。

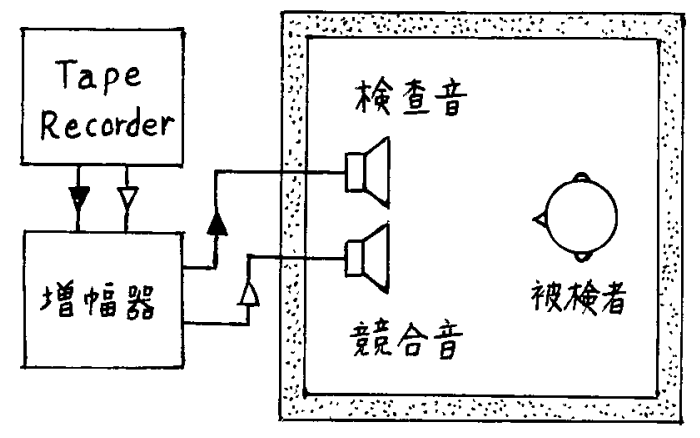

図3検查音 $60 \mathrm{~dB}$

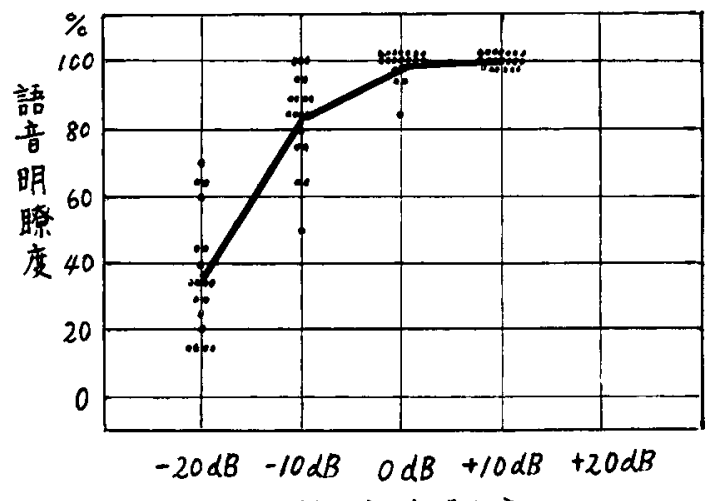

検查音/競合音比 